\title{
Analgesic Usage in Elderly at Public Health Center: A study in West Java, Indonesias
}

\author{
Gembong Soeyono Putro, ${ }^{1}$ Herri S. Sastramihardja, ${ }^{2}$ Lazuardhi Dwipa ${ }^{3}$ \\ ${ }^{1}$ Faculty of Medicine Universitas Padjadjaran, ${ }^{2}$ Department of Pharmacology and Therapy Faculty \\ of Medicine Universitas Padjadjaran, ${ }^{3}$ Department of Internal Medicine Faculty of Medicine \\ Universitas Padjadjaran/Dr. Hasan Sadikin General Hospital Bandung
}

\begin{abstract}
Background: Various analgesics prescriptions for elderly are not appropriate according to the guideline and can cause the increase of side effects such as gastric problems. Puskesmas as a public health center in Indonesia has an important role in anticipating this problem. The objectives of this study was to identify the analgesic usage in elderly patients at the public health center.

Methods: This retrospective descriptive study was conducted for 3 months at Tanjungsari public health center, Sumedang, West Java, Indonesia, using total sampling. The data was taken from 417 medical records from 2013. The data taken from medical records were: sex, analgesic drug, diagnosis, and drug for gastric problem.

Results: From the collected data, the most analgesics prescribed for the elderly patients was paracetamol, followed by Piroxicam, Mefenamic acid, and Ibuprofen. Not all of the elderly patients who received NSAIDs, were given gastric drug.

Conclusions: The most prescribed analgesic drug given to elderly patients at the public health center is paracetamol. [AMJ.2017;4(1):16-9]
\end{abstract}

Keywords: Analgesics, elderly, primary health care, public health center

\section{Introduction}

Indonesia is expected to become a country with aging population in 2050, in which the ratio of older adult ( $>60$ years) is more than the population aged $<15$ years. This situation occurs because of the increase of life expectancy. ${ }^{1}$

Doctors often underestimate the analgesic drug administration in older adult patients, whereas the administration of analgesic drugs in older adult patients is different from other age groups. This is due to the increased risk of side effects and decreasing physiological condition of older adult patients. ${ }^{2}$ Analgesic drug administration should be in accordance with the prevailing procedures, which is based on the World Health Oorganization (WHO) Pain Ladder, where the administration of drugs should be started from the bottom of the order to be continued to the next order if the pain is still there or getting worse. Analgesic prescription in older adult patient should be accompanied by adjuvant drug, to avoid potential side effects and improving the drug effectiveness. ${ }^{3,4}$

Side effects that usually arise from the administration of analgesic drugs including cardiac and renal dysfunction and toxic effects on the digestive tract and stomach disorders. ${ }^{5,6}$ The use of NSAID in older adult patients increase the risk of side effects such as gastrointestinal disturbances over as much as $50 \%$ and as much as $15 \%$ of older adult patients with symptoms of rheumatoid arthritis stop the use of NSAID due to the onset of complaints of stomach ulcers. ${ }^{7}$

Along with the increased likelihood of side effects to occur in older adult patients, it is necessary to administer drugs in a rational way to avoid unwanted side effects. Public Helath Center (Pusat Kesehatan Masyarakat, Puskesmas) as the primary health care provider in Indonesia has an important role in anticipating this problem, due to ease of access and entry into the Indonesian

Correspondence: Gembong Soeyono Putro, Faculty of Medicine, Universitas Padjadjaran, Jalan Raya Bandung-Sumedang Km.21, Jatinangor, Sumedang, Indonesia, Phone: +62 91285247252 Email: gembongsoeyonoputro@gmail.com 
Table 1 Amount of Analgesic Drug Use at Tanjungsari Public Health Center in Older Adult Patients in 2013

\begin{tabular}{lcc}
\hline \multicolumn{1}{c}{ Drug Name } & Total Usage & Percentage \\
\hline Ibuprofen & 46 & $10 \%$ \\
Paracetamol & 315 & $56 \%$ \\
Mefenamic Acid & 46 & $10 \%$ \\
Piroxicam & 54 & $12 \%$ \\
Total & 461 & $100 \%$ \\
\hline
\end{tabular}

government's health insurance system the Jaminan Kesehatan Nasional (National Health Coverage) which requires the patient to go to public health care in advance. ${ }^{8}$

Of all the problems mentioned previously, the objective of this study was to identify the analgesic usage in elderly patients at the public health center.

\section{Methods}

The study was conducted from August 2014 to October 2014 at the Tanjungsari public health care in Sumedang West Java. The data used in this study were taken from the medical records of older adult patients ( $>60$ years) who were given analgesics at Tanjungsari public health center in 2013. Data obtained from the patient's medical record were: the patient's age, sex of the patient, patient's diagnosis, name of the analgesic drug given, and if any provisions of NSAIDs were also given gastric medication or not. Then, the data were processed using computer and presented in tabular form. The data collection used the total sampling method and a total number of 417 patients were obtained which comprised 165 male and 252 female patients.

The use of medical records was approved by the Health Research Ethics Committee Faculty of Medicine Universitas Padjadjaran, Sumedang City's Development Planning Board, and Sumedang City Health Department.

\section{Results}

According to collected data, various analgesics were used among elderly. This study discovered that Paracetamol was the most used analgesic among elderly patients $(315,68 \%)$ compared to other analgesics, followed by Piroxicam, Mefenamic acid, and ibuprofen. A hundred

Table 2 Diagnosis of Elderly with Bone, Muscle and Connective Tissue Disorders

\begin{tabular}{lcc}
\hline \multicolumn{1}{c}{ Diagnosis } & Total & Percentage \\
\hline Bone, muscle, and connective tissue & 57 & $100 \%$ \\
Polyarthritis & 25 & $44 \%$ \\
Myalgia & 22 & $38 \%$ \\
Rheumatic & 9 & $16 \%$ \\
Reactive athropathy & 1 & $2 \%$ \\
\hline
\end{tabular}

Table 3 Number of Elderly Who Received NSAIDs and Gastric Medication at Tanjungsari Public Health Center in 2013

\begin{tabular}{lcc}
\hline & Total & Percentage \\
\hline NSAID with gastric medication & 64 & $33 \%$ \\
NSAID without gastric medication & 125 & $67 \%$ \\
Total & 189 & $100 \%$ \\
\hline
\end{tabular}


four from 417 patients (24.9\%) were given more than one kind of analgesic (Table 1).

Out of 417 medical records obtained, only 57 patients were diagnosed with bone, muscle and connective tissue disorders that indicated the prescription of analgesics (Table 2).

One of the highest side effects of the use of analgesics, especially from the class of NSAIDs was stomach irritation. Gastric drug usage of NSAID prescribed to older adult patients can be seen on Table 3 . There were 64 patients out of 189 patients who were given gastric drug as adjuvant to NSAID prescription, while the remaining 125 patient did not receive gastric drug as adjuvant to NSAID prescription.

\section{Discussion}

This study discovered that there were more female patients attending primary care clinics and given analgesics compared to male patients. This was consistent with a study conducted by Miro et al. ${ }^{9}$ which states that women complain of pain more than men, and the sites of grievances are joint, lower extremities, spine and neck. ${ }^{9}$

Additionally, paracetamol is the most prescribed analgesic in older adult patients at Puskesmas Tanjungsari in 2013, this is in accordance with a study conducted by Won et al. ${ }^{10}$ which states that of the administration of analgesic drugs, the most common are paracetamol (37.2\%), propoxyphene $(18.2 \%)$, hydrocodone $(6.8 \%)$, and tramadol $(5.4 \%){ }^{10}$ This is strengthened also by a study conducted by Barber et al. ${ }^{11}$ which states that paracetamol is an analgesic drug that tends safe to be consumed because it has low side effects on gastric and kidneys function. ${ }^{11}$ According to another study conducted by O'Neil et al. ${ }^{12}$ paracetamol should be the frontline for treating pain symptoms, while the use of NSAID should be considered for short-term used and for moderate to severe pain only, and the usage of opioid analgesic is preferable for older age patients without substance abuse or dependence issues. ${ }^{12}$

Furthermore, for the use of NSAIDs in older adult patients generally accompanied with gastric medication, this is done to prevent the side effects of gastric irritation. ${ }^{13}$ According to a study conducted by Rahme et al. ${ }^{14}$ the use of NSAIDs in the older adult are at greater risk of developing gastrointestinal side effects compared to older adult patients given lowdose paracetamol. ${ }^{14}$ According to Thiéfin et ${ }^{1} .^{15}$, in France, only half of NSAID users (above 65 years old) receive gastrointestinal protective agents, which is in accordance to this study. ${ }^{15}$ According to the data of this study, from 313 older adult patients who are prescribed NSAID only 68 patients (32\%) are given gastric drug as a companion of NSAID. From these data, it is concluded that gastric drug used as an adjuvant drug of NSAID in older adult patients is still low, while as noted above, the possibility of adverse effects on gastric increase as well as increase of the age.

Limitations of this study were incomplete filling of medical records. It can be seen from the lack of information on drug dosage, duration of use, and patient's chief complaints or symptoms. A better record keeping on medical records is needed for completeness of archives and for subsequent studies.

In general, it can be concluded that the most used of analgesic drugs at the Tanjungsari public health center for older adult patients in 2013 is paracetamol. Prescriptions for analgesic in older adult patients in Tanjungsari public health center are still not proper, especially in the administration of NSAIDs; it can be seen from the number of older adult patients who are given NSAIDs without the accompany of gastric drug, which can cause harmful side effects in the form of gastric disorders.

\section{References}

1. Pusat Data dan Informasi Kementerian Kesehatan RI. Gambaran kesehatan lanjut usia di Indonesia. Jakarta: Kementerian Kesehatan RI; 2013.

2. Routledge P, O'Mahony M, Woodhouse K. Adverse drug reactions in elderly patients. Br J Clin Pharmacol. 2004;57(2):121-6.

3. World Health Organization. WHO's pain ladder for adults. Geneva: World Health Organization; 2013.

4. Tracy B, Sean Morrison R. Pain management in older adults. Clin Ther. 2013;35(11):1659-68.

5. Cavalieri TA. Managing pain in geriatric patients. JAOA: J Am Osteopath Assoc. 2007;107(suppl 4):ES10-6.

6. Rastogi R, Meek BD. Management of chronic pain in elderly, frail patients: finding a suitable, personalized method of control. Clin Interv Aging. 2012;8:37-46.

7. Pilotto A, Sancarlo D, Addante F, Scarcelli C, Franceschi M. Non-steroidal antiinflammatory drug use in the elderly. Surg Oncol. 2010;19(3):167-72.

8. Kementerian Kesehatan Republik Indonesia. Riset Kesehatan Dasar. Jakarta: 
Badan Penelitian Dan Pengembangan Kesehatan Kementrian Kesehatan Republik Indonesia; 2006.

9. Miró J, Paredes S, Rull M, Queral R, Miralles $\mathrm{R}$, Nieto $\mathrm{R}$, et al. Pain in older adults: a prevalence study in the Mediterranean region of Catalonia. Eur J Pain. 2007;11(1):83-92.

10. WonAB,LapaneKL,VallowS,ScheinJ,Morris JN, Lipsitz LA. Persistent nonmalignant pain and analgesic prescribing patterns in elderly nursing home residents. Am J Geriatr Soc. 2004;52(6):867-74.

11. Barber JB, Gibson SJ. Treatment of chronic non-malignant pain in the elderly. Drug safety. 2009;32(6):457-74.

12. O'Neil CK, Hanlon JT, Marcum ZA. Adverse effects of analgesics commonly used by older adults with osteoarthritis: focus on non-opioid and opioid analgesics. Am J
Geriatr Pharmacother. 2012;10(6):33142.

13. Campanelli CM. American Geriatrics Society updated Beers criteria for potentially inappropriate medication use in older adults: The American Geriatrics Society 2012 Beers criteria update expert panel. J Am Geriatr Soc. 2012;60(4):61631.

14. Rahme E, Barkun A, Nedjar H, Gaugris S, Watson D. Hospitalizations for upper and lower GI events associated with traditional NSAIDs and acetaminophen among the elderly in Quebec, Canada. Am J Gastroenterol. 2008;103(4):872-82.

15. Thiéfin G, Schwalm M-S. Underutilization of gastroprotective drugs in patients receiving non-steroidal anti-inflammatory drugs. Dig Liver Dis. 2011;43(3):209-14. 